\title{
Seagrass losses concerns: does sediment metal pollution matter?
}

\author{
Clarissa Lourenço de Araujo ${ }^{1 *}$ \\ Daniel Dias Loureiro ${ }^{1}$ \\ Marcos Manoel Ferreira ${ }^{1}$ \\ Luiz Drude de Lacerda ${ }^{2}$ \\ Marcos Antonio Fernandez ${ }^{3}$ \\ Wilson Thadeu Valle Machado ${ }^{1}$ \\ ${ }^{1}$ Departamento de Geoquímica, Instituto \\ de Química, Universidade Federal \\ Fluminense (UFF) - Niterói (RJ), Brazil. \\ ${ }^{2}$ Instituto de Ciências do Mar, \\ Universidade Federal do Ceará (UFC) - \\ Fortaleza (CE), Brazil. \\ ${ }^{3}$ Faculdade de Oceanografia, Universidade \\ do Estado do Rio de Janeiro (UERJ) - \\ Rio de Janeiro (RJ), Brazil.
}

*Autor correspondente: lourenco.cla@gmail.com

\begin{abstract}
Seagrass losses result in the lost of well-known environmental services (e.g. nutrient retention and habitat functions). A potential additional loss is the enhanced trace metal retention capacity of sediments colonized by seagrasses. A preliminary study within a coastal lagoon in SE Brazil showed that upper layers of sediments colonized by the seagrass Ruppia maritima presented significantly higher reactive concentrations of $\mathrm{Fe}, \mathrm{Mn}, \mathrm{Cu}$, and $\mathrm{Zn}$ than sediments from an adjacent bare area. Decreasing metal trapping capacity due to $R$. maritima removal deserves attention, since this is a potential implication for water quality.
\end{abstract}

Keywords: Ruppia maritima, seagrass services, trace metals.

\section{Resumo}

Perdas de áreas de fanerógamas marinhas resultam na perda de serviços ambientais bem conhecidos (por exemplo, a retenção de nutrientes $e$ as funções de hábitat). Uma potencial perda adicional é a capacidade aumentada da retenção de metais-traço em sedimentos colonizados por estas fanerógamas. Um estudo preliminar realizado em uma lagoa costeira do Sudeste do Brasil mostrou que as camadas superiores dos sedimentos colonizados pela fanerógama marinha Ruppia maritima apresentaram concentrações reativas de $\mathrm{Fe}, \mathrm{Mn}$, $\mathrm{Cu}$ e $\mathrm{Zn}$ significativamente maiores do que sedimentos de uma área adjacente sem cobertura vegetal. A capacidade reduzida da retenção de metais devido à remoção de $\mathrm{R}$. maritima merece atenção, pois apresenta potenciais implicações para a qualidade da água. Palavras-chave: Ruppia marítima, serviços de fanerógamas marinhas, metais-traço. 


\section{INTRODUCTION}

Seagrasses, a group of plants that are adapted to exist submerged in the sea, profoundly influence the physical, chemical and biological environments of coastal waters and provide numerous ecological services (Thangaradjou et al. 2013). They can affect coastal sediments biogeochemistry, e.g. by increasing the deposition of fine particles and sediment stabilization and adding organic matter, which fuel sulfide production (De Boer 2007, Viaroli et al.1997). These effects are of particular interest in areas that receive anthropogenic metals input, which may also affect seagrass communities (Ward \& Young 1983, Marín-Guirao et al. 2005). Several monitoring programmes have successfully used marine macrophytes to quantify contamination loads with trace metals (Haritonidis \& Malea 1999). Indeed, because plants have a high capacity to accumulate a range of elements, their widespread use as indicators of marine pollution seems justified (Lytle \& Lytle 2001).

Metal sulfides, organic matter, and oxidized forms of $\mathrm{Fe}$ and $\mathrm{Mn}$ are recognized as main controls on trace metal behavior in coastal sediments, which are also affected by sediment physicochemical conditions (Chapman et al. 1998). Therefore, the translocation of photosynthetically produced $\mathrm{O}_{2}$ and its release by seagrass roots into the substrate may also be important (Hebert et al. 2007, Povidisa et al. 2009). This release has been observed for Ruppia maritima (Thursby 1984), which is the most widely distributed seagrass species (Short et al. 2007).

\section{MATERIALS AND METHODS}

Two short sediment cores (0 to $20 \mathrm{~cm}$ depth) were sampled in May 2009, by driving acrylic tubes into the sediments near the edge of an approximately two-year-old $R$. maritima bed in the lagoon margin (Figure 1; 22 $2^{\circ} 8^{\prime} 0.07^{\prime \prime} \mathrm{S}$, $\left.43^{\circ} 12^{\prime} 58.06^{\prime} \mathrm{W}\right)$. The first core was collected inside the
The distribution of acid-volatile sulfides (AVS) and simultaneously extracted metals (SEM) in sediments colonized by R. maritima was evaluated in Rodrigo de Freitas Lagoon (Rio de Janeiro State, Brazil), which is considered one of the most polluted coastal lagoons in SE Brazil, impacted by untreated sewage input and urban runoff. The lagoon is a semi-confined system making water renewal complex and the marine water flux is superficial, leaving deeper layers unaffected (Fonseca et al. 2014). Extreme reducing conditions within the lagoon are due to the high concentration of organic matter, low currents and limited exchanges with the sea, making ideal conditions for the accumulation of pollutants, such as trace metals (Kim et al. 2011).

Details on this eutrophicated system contamination history are available elsewhere (Lacerda \& Gonçalves 2001, Loureiro et al. 2009). At least since nearly 2008, the government management policy to improve environmental and esthetical quality of the lagoon included the periodical removal of seagrass beds from its margins. We discuss here, based on preliminary analysis of seagrass bed sediments, the potential effects of the colonization by $R$. maritima on the sediment capacity to trap trace metal contaminants, such as $\mathrm{Cu}, \mathrm{Pb}$ and $\mathrm{Zn}$ and possible implications of seagrass removal on this trapping (Loureiro et al. 2009). seagrass bed (core $\mathrm{R}$ ) and the second one in the bare adjacent area (core U), both distanced nearly $3 \mathrm{~m}$ from the bed edge. Live and dead roots and rhizomes were observed within the upper $10 \mathrm{~cm}$ depth of core R. The sediments were sub-sampled in 0 to 2,2 to 4,4 to 6,6 to 8,8 to 10,12 to

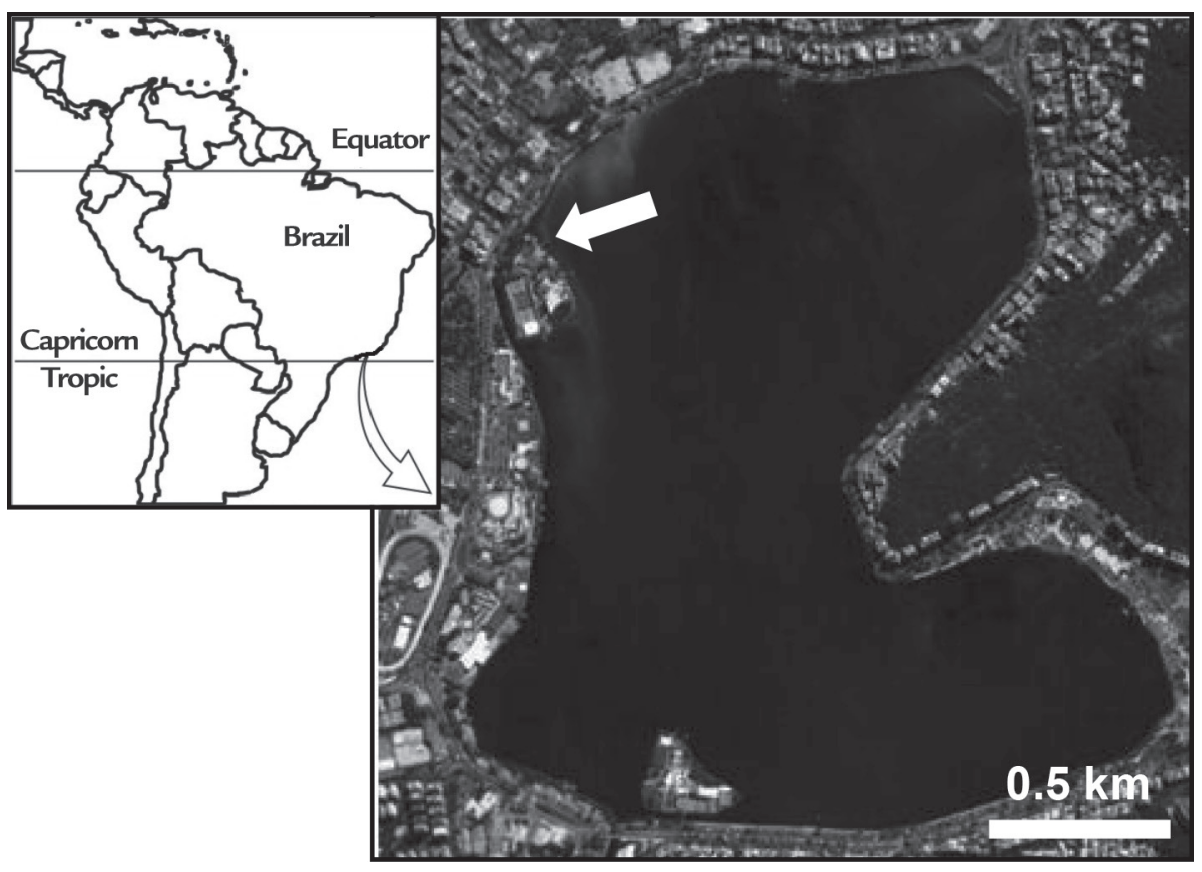

Figure 1

Location of sampling site (indicated by an arrow) within Rodrigo de Freitas Lagoon, SE Brazil. 
14 and 16 to $18 \mathrm{~cm}$ depth intervals and kept refrigerated until analyses. AVS and SEM extractions were carried out in duplicates, according to the acid (6 mol $1-1 \mathrm{HCl})$ distillation method (Allen et al. 1991). AVS levels were determined gravimetrically after precipitation of the evolved sulfide $\left(\mathrm{H}_{2} \mathrm{~S}\right)$ as $\mathrm{Ag}_{2} \mathrm{~S}$ (Allen et al. 1991). Simultaneously extracted $\mathrm{Fe}, \mathrm{Mn}$, $\mathrm{Cu}, \mathrm{Pb}$ and $\mathrm{Zn}$ levels were determined by ICP OES.

Reproducibility was within 30 (AVS) and 15\% (metals). Sediment water content was determined after drying to con-

\section{RESULTS AND DISCUSSION}

Vertical distributions of AVS and metals were consistently different between cores, frequently showing inverse trends, with higher contents observed in upper layers of core $\mathrm{R}$ for all metals (Figure 2). These metals presented relatively few significant correlations $(\mathrm{p}<0.05)$ with studied sediment properties, as indicated by Spearman's correlation analyses. In the core, $\mathrm{R}, \mathrm{Pb}$ and $\mathrm{Zn}$ were correlated ( $\mathrm{rs}=0.89)$, as well as Fe and $\mathrm{Mn}(\mathrm{rs}=0.96)$, while $\mathrm{Cu}$ was correlated with $\mathrm{Fe}(\mathrm{rs}=0.89)$ and $\mathrm{Mn}(\mathrm{rs}=0.86)$. In the core $\mathrm{U}$, there were correlations of $\mathrm{Fe}$ with $\mathrm{Mn}(\mathrm{rs}=0.96)$ and $\mathrm{Pb}$ with $\mathrm{Zn}(\mathrm{rs}=0.96)$, and $\mathrm{Pb}$ was also correlated with $\mathrm{Fe}$ $(\mathrm{rs}=0.79)$ and $\mathrm{Mn}(\mathrm{rs}=0.86)$, while $\mathrm{Zn}$ was correlated with $\mathrm{Mn}$ ( $\mathrm{rs}=0.82$ ).

This evidenced an association of trace metals with reactive $\mathrm{Fe}$ and $\mathrm{Mn}$, without significant correlations with AVS, indicating that reactive $\mathrm{Mn}$ and $\mathrm{Fe}$ compounds are main geochemical carriers. Metal contaminant associations with $\mathrm{Fe}$ and $\mathrm{Mn}$ are frequently observed in coastal sediments, as reported for other parts of Rodrigo de Freitas Lagoon stant weight $\left(60^{\circ} \mathrm{C}, 48\right.$ hours). Visual examination evidenced grain size differences between cores and a sediment grain size analysis was carried out for some representative depth intervals ( 0 to 2,4 to 6,8 to 10 and 16 to $18 \mathrm{~cm}$ ) by using a CILAS particle size meter. Data were treated using the software XLSTAT-Pro $7.0^{\circ}$. The significance of the observed differences in concentrations between cores and surface and deeper layers in each core was tested using Mann-Whitney's test $(\mathrm{p}<0.05)$ and Spearman's correlation analyses $(\mathrm{p}<0.05)$.

(Loureiro et al. 2009). The correlations between trace metals can indicate similar geochemical behavior and metal source similarity, as previously found for $\mathrm{Cu}, \mathrm{Pb}$ and $\mathrm{Zn}$ that are mostly affected by urban effluents inputs to Rodrigo de Freitas Lagoon (Loureiro et al. 2009).

Despite any possible sand dilution effect due to a coarser grain size in vegetated sediments than in bare sediments ( 11 to $23 \%$ versus 27 to $45 \%$ sand contents, respectively, for the analyzed depth intervals), core $\mathrm{R}$ presented levels that are similar to or higher than those found in core $\mathrm{U}$ for all elements within the 0 to $8 \mathrm{~cm}$ depth (Figure 2). For this interval, a Mann-Withney U test indicated significant ( $\mathrm{p}=0.02$ to 0.04 ) differences for all metals, with the exception of $\mathrm{Pb}$. Besides the seagrass stabilization of sediments against resuspension (De Boer 2007), a coupled effect of the observed reactive $\mathrm{Fe}, \mathrm{Mn}$ and AVS enrichments near the sediment-water interface is expected to occur, favoring metal retention in the solid-phase (Keene et al. 2010, Nizolo \& Luiz-Silva 2012).
Figure 2

Depth variability in acid-volatile sulfides (AVS) and reactive $(\mathrm{HCl}$ extractable) metal concentrations

from the seagrass-covered (core $\mathrm{R}$, filled symbols) and unvegetated (core $U$, open symbols) sediments. Dashed horizontal lines represent the approximated maximum rhizosphere depth observed in core $\mathrm{R}$ sediments.
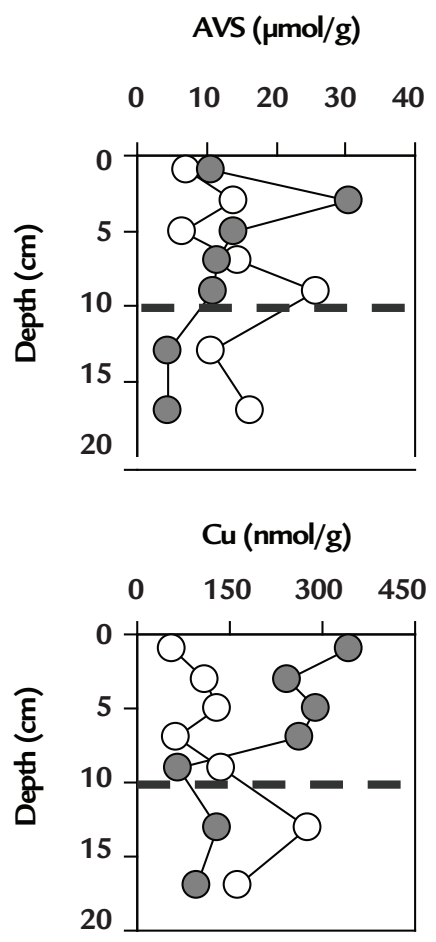

$\mathrm{Fe}(\mu \mathrm{mol} / \mathrm{g})$

$\mathrm{Mn}(\mu \mathrm{mol} / \mathrm{g})$
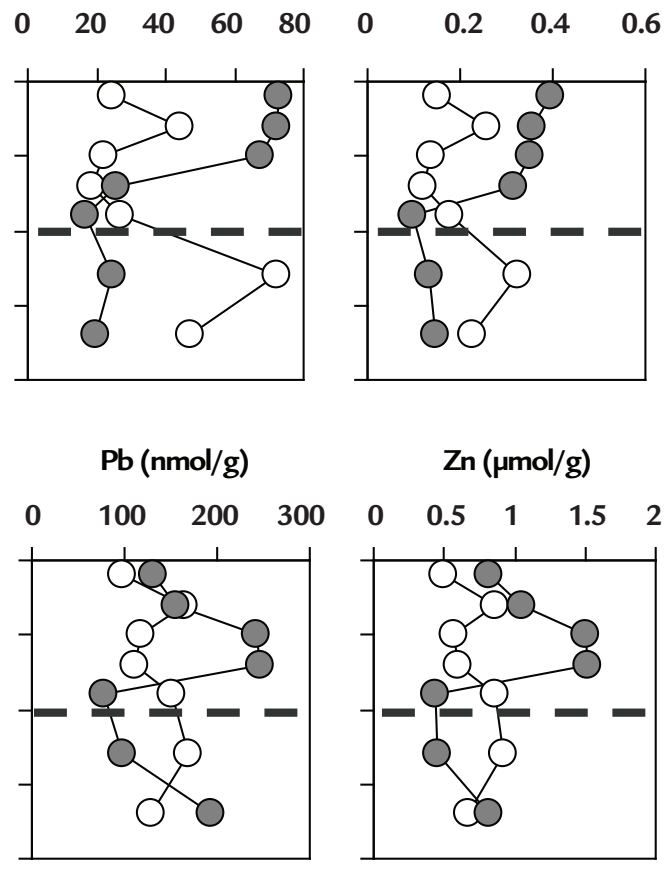
For example, while there is sufficient AVS to react with SEM, these metals (that form monosulfides more stable than $\mathrm{FeS}$, assumed as the main AVS constituent) will not be accumulated in the pore water due to removal in reaction with AVS (Chapman et al. 1998). The molar ratios between SEM ( $\mathrm{Cu}, \mathrm{Pb}$ and $\mathrm{Zn}$, in this case) and AVS were up to 0.13 and 0.18 , for cores $U$ and $R$, respectively, thus the sediment capacity to retain these metals in the form of AVS was not exhausted.

Organic matter input from the seagrass debris must fuel sulfide production close to the sediment-water interface
(Viaroli et al. 1997). In the study site, there was probable additional organic matter input from the observed extensive epiphytic cover of $R$. maritima leaves (mainly by filamentous alga Cladophora sp.), while rhizosphere oxidation was not evident by visual examination (e.g. reddish iron plaque cover on the seagrass roots) (Povidisa et al. 2009), possibly due to a recent colonization. Hebert et al. (2007) did not see a 'ventilation' effect by seagrasses, so bioturbation may mask this observation.

Figure 3 presents the relative differences between trace metal concentrations for each sediment layer in $R$.

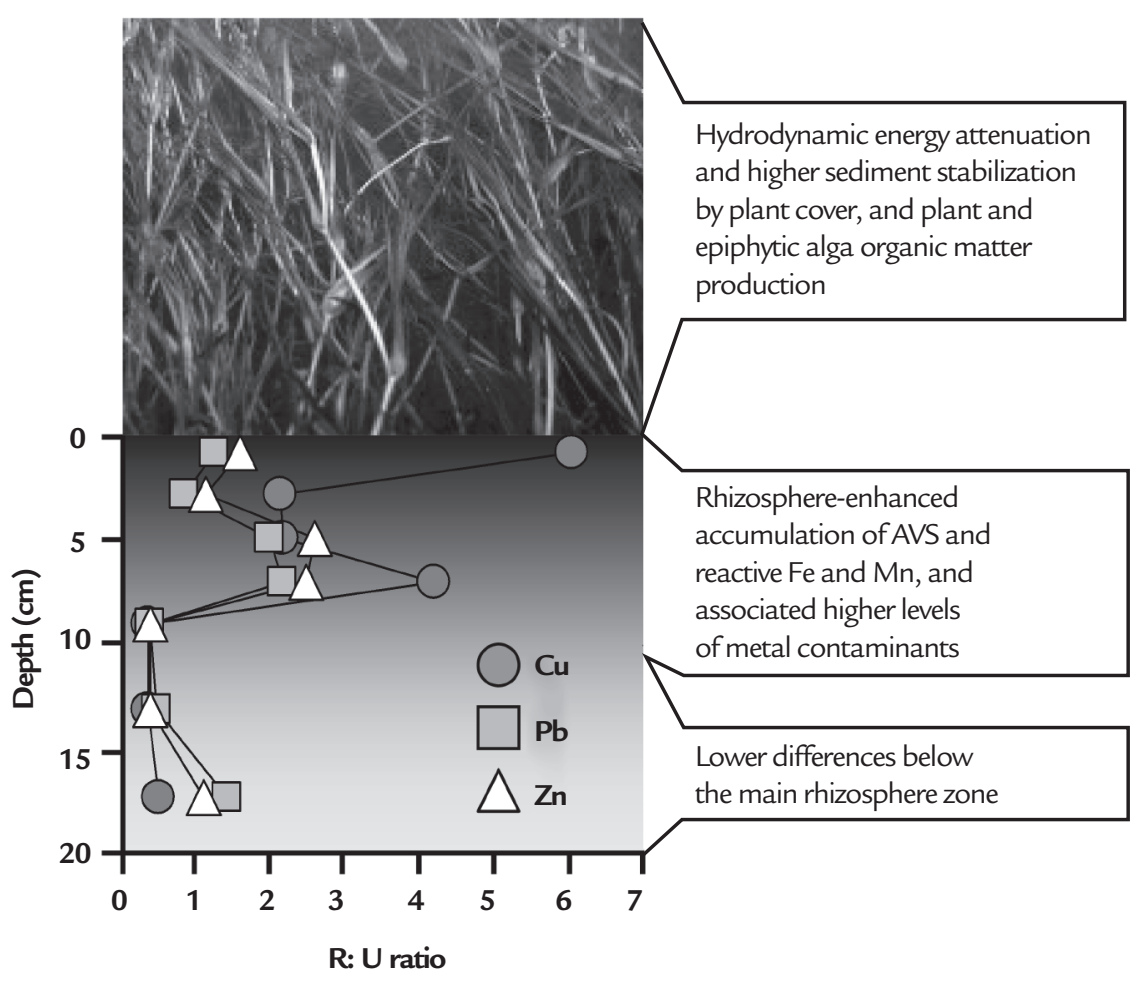

Figure 3

Depth variability of the relative enrichment in trace metal concentrations in R. maritima- colonized sediments (core $\mathrm{R}$ ) in relation to unvegetated sediments (core $U$ ) in the study site ( $R: U$ ratios), and schematic synthesis of main processes involved in determining such enrichments. Upward gray shading indicates the increasing effect of $\mathrm{R}$. maritima rhizosphere and input of plant and epiphytic alga debris on upper sediment layers. maritima-colonized sediments (core $\mathrm{R}$ ) in relation to unvegetated sediments (core $U$ ) in the study site (hereafter referred to as $\mathrm{R}: \mathrm{U}$ ratios), demonstrating that these metals presented highly variable sensitivities $(\mathrm{Cu}>>\mathrm{Zn}>\mathrm{Pb})$ to plant cover influence. Within the upper $8 \mathrm{~cm}$ depth, $\mathrm{Cu}$ presented R:U ratios between 2.2 and 6.0 in comparison to values ranging in 0.9 to $2.2(\mathrm{~Pb})$ and 1.2 to $2.6(\mathrm{Zn})$ showed by other trace metals, whereas all amounts below this depth (i.e. bellow the main rhizosphere influence zone) ranged from 0.5 to 1.5 for the three metals. Although all elements have an affinity to sulfides (Marín-Guirao et al. 2005), the well-recognized affinity of $\mathrm{Cu}$ to organic matter (e.g. as previously found in seagrass-colonized sediments) can contribute to explaining the observed higher sensitivity to plant colonization, in addition to the observed associations with reactive Fe and Mn (Ward \& Young 1983).

Daby (2003) reported that seagrass removal caused high turbidity in waters overlying a destabilized lagoon seabed and complete loss of benthic fauna, rendering the ecosystem more vulnerable to environmental change and extreme events. The preliminary study presented here suggests that a less evident role of seagrass beds may also be lost, i.e. the influence on the sediment capacity to retain trace metals. This function loss may increase sediment release of metals, e.g. due to enhanced resuspension of sediments, which may have implications for water quality (Morse 1994, Machado et al. 2011). In fact, seagrass-colonized sediments have been recently evidenced as potential long-term sinks for trace metals, as recorded in a long sediment core from a Mediterranean site (Serrano et al.2011). 


\section{CONCLUSIONS}

Although the seagrass-colonized sediments showed a coarser nature, its upper layers presented AVS and metal levels similar to or higher than those found in the unvegetated core, indicating the influence of seagrass colonization. Besides the physical stabilization of sediments and organic matter input (well-known in segrass ecosystems), this preliminary study indicated that an enrichment in reactive $\mathrm{Fe}$, $\mathrm{Mn}$ and AVS near the sediment-water interface also favors

\section{ACKNOWLEDGEMENTS}

We would like to thank Doctor R. C. Cordeiro for providing grain size analysis and the National Research Council (CNPq), Brazilian Ministry of Education (CAPES), metal retention in sediments under the R. maritima influence, occurring a high variability in the sensitivity of metals to these effects. While there is already a concern with the loss of enviromental services (e.g. nutrient retention and habitat functions) due to seagrass removal worldwide because of anthropogenic pressures (Orth et al.2006, Short et al.2007), investigation on a potential additional service loss regarding trace metal mobility is recommended. and Research Foundation of Rio de Janeiro State (FAPERJ) for their research grants. This study was part of the INCTTMCOcean (CNPq), Process number 573.601/2008-9.

\section{REFERENCES}

Allen H.E., Fu G., Boothman W., Di Toro D., Mahony J.D. 1991. Determination of acid volatile sulfides and selected simultaneously extractable metals in sediment. Environmental Protection Agency, Narragansett, RI (United States), 1-22.

Chapman P.M., Wang F., Janssen C., Persoone G., Allen H.E. 1998. Ecotoxicology of metals in aquatic sediments: binding and release, bioavailability, risk assessment, and remediation. Canadian Journal of Fisheries and Aquatic Science, 55:2221-2243.

Daby D. 2003. Effects of seagrass bed removal for tourism purposes in a Mauritian bay. Environmental Pollution, 125:313-324.

De Boer W.F. 2007. Seagrass-sediment interactions, positive feedbacks and critical thresholds for occurrence: A review. Hydrobiologia, 591:5-24.

Fonseca E.M, Baptista Neto J.A., McAlister J.J., Smith B.J., Crapez M.A.C. 2014. Bioavailability of pollutants in bacterial communities of Rodrigo de Freitas Lagoon, Rio de Janeiro, Brazil. Brazilian Journal of Microbiology, 45(3):953-962.

Haritonidis S. \& Malea P. 1999. Bioaccumulation of metals by the green alga Ulva rigida from Thermaikos Gulf, Greece. Environmental Pollution, 104:365-372.

Hebert A.B., Morse J.W., Eldridge P.M. 2007. Small-scale heterogeneity in the geochemistry of seagrass vegetated and non-vegetated estuarine sediments: causes and consequences. Aquatic Geochemistry, 13:19-39.

Keene A.F., Johnston S.G., Bush R.T., Burton E.D., Sullivan L.A. 2010. Reactive trace element enrichment in a highly modified, tidally inundated acid sulfate soil wetland: East Trinity, Australia. Marine Pollution Bulletin, 60:620-626.

Kim K.T., Ra K., Kim E.S., Yim U.H., Kim J.K. 2011. Distribution of Heavy Metals in the Surface Sediments of the Han River and its Estuary, Korea. Journal of Coastal Research, 64:903-907.

Lacerda L.D. \& Gonçalves, G.O. 2001. Mercury distribution and especiation in waters of the coastal lagoons of Rio de Janeiro, SE Brazil. Marine Chemistry. Marine Chemistry, 76:47-58.

Lytle J.S. \& Lytle T. F. 2001. Use of plants for toxicity assessment of estuarine ecosystems. Environmental Toxicology and Chemistry, 20:68-83.

Loureiro D.D., Fernandez M.A., Herms F.W., Lacerda L.D. 2009. Heavy metal inputs evolution to an urban hypertrophic coastal lagoon, Rodrigo De Freitas Lagoon, Rio De Janeiro, Brazil. Environmental Monitoring and Assessment, 159:577-588. 
Machado W., Rodrigues A.P.C., Bidone E.D., Sella S.M., Santelli R.E. 2011. Evaluation of $\mathrm{Cu}$ potential bioavailability changes upon coastal sediment resuspension: an example on how to improve the assessment of sediment dredging environmental risks. Environmental Science and Pollution Research., 18:1033-1036.

Marín-Guirao L., Atuch, A.M., Barba J.L., López E.M., Fernández A.J.G. 2005. Effects of mining wastes on a seagrass ecosystem: metal accumulation and bioavailability, seagrass dynamics and associated community structure. Marine Environmental Research, 60:317-337.

Morse J.W. 1994. Mar. Chem., 46:1-6.

Orth, R.J., Carruthers,T.J.B., Dennison,W.C., Duarte,C.M., Fourqurean, J.W., Heck Jr., K.L., Hughes A.R., Kendrick G.A., Kenworthy W.J., Olyarnik S., Short F.T., Waycott M., Williams S.L. 2006. A global crisis for seagrass ecosystems. BioScience, 56:987-996.

Povidisa K., Delefosse M., Holmer M. 2009. The formation of iron plaques on roots and rhizomes of the seagrass Cymodocea serrulata (R. Brown) Ascherson with implications for sulphide intrusion. Aquatic Botany, 90:303-308.

Serrano O., Mateo M.A., Dueñas-Bohórquez A., Renom P., López-Sáez J.A., Martínez Cortizas A. 2011. The Posidonia oceânica marine sedimentar record: a holocene archive of heavy metal pollution. Science of the Total Environment, 409:4831-4840.

Short F., Carruthers T., Dennison W., Waycott M. 2007. Global seagrass distribution and diversity: a bioregional model. Journal of Experimental Marine Biology and Ecology, 350:3-20.

Thursby G.B. 1984. Nutritional requirements of the submerged angiosperm Ruppia maritima in algae-free culture. Marine Ecology Progress Series, 16:45-50.

Viaroli P., Bartoli M., Fumagalli I., Giordani G. 1997. Relationship between benthic fluxes and macrophyte cover in a shallow blackish lagoon. Water, Air, and Soil Pollution, 99:533-540.

Ward T.J. \& Young P.C. 1983. Effects of sediment trace metals and particle size on the community structure of epibenthic seagrass fauna near a lead smelter, South Australia. Marine Ecology Progress Series, 9:137-146. 